\title{
OVERVIEW ABOUT THE MANAGEMENT OF THE HUMAN RESOURCE IN PROJECTS
}

\author{
Catalin Drob \\ "Vasile Alecsandri” University of Bacau \\ catad@ub.ro
}

\begin{abstract}
The purpose of this study is to emphasize the main aspects regarding the management of the human resource in projects. This study tries to present in the comparative manner, different approaches of several guidelines, international standards and methodologies regarding the management of the human resource in projects (the PMBOK ${ }^{\circledR}$ Guide elaborated by the Project Management Institute and the PRINCE method elaborated by the British Office of Government Commerce). The PMBOK® Guide describes four elements (processes) of human resource management: human resource planning, acquire project team, develop project team and manage project team. The PMBOK approach regarding human resource management is focused on utilizing the people involved in the project in the best way. According the PRINCE method the management of the human resource is focused on the roles and responsibilities of the human resource within the project. In this standard, the responsibilities are viewed like a roles. Everybody involved in the project can have one or more roles and a role can be fulfilled by several persons.
\end{abstract}

\section{Keywords}

Human resource; project; project team; project manager; board manager

\section{JEL Classification}

M54

\section{Introduction}

Within a project are used several types of resources: material, human, financial and informational. The most important resource used within a project is the human resource, more precisely, the project team. The project team is leading the project to success or to failure.

But what are the factors (related to the project team) that can contribute to the success of the project? There are many factors but perhaps the most important factor is to know how to select the best people able to achieve the project goals and to make them to work as a really team. Achieving this desideratum represents a real challenge because the project team can be made up of people coming from different organizations. The project team may be established based on (but not compulsory) three components: core team, client team and contract team. Thereby, the project manager has very important role to harmonize these heterogeneous components and to manage them appropriately.

In the last years, have been developed several guides, standards and methods concerning the project management, such as: the PMBOK®Guide, the PRINCE method, the P2M guidebook etc. As appropriate, these guides, standards and methods analyze, among other things, the issue of human resources within projects in more detail (within the PMBOK®Guide and the PRINCE method) or more succinctly (within the P2M guidebook). 


\section{Human resource management according the PMBOK®Guide}

This guide provides guidelines, general and specific rules for project management. In 1996 the Project Management Institute (PMI) published the first edition of this guide. The last edition (the fifth edition) of this guide was published in 2012.

The PMBOK ${ }^{\circledR}$ Guide considers that Project human resource management is one of the most important knowledge areas of the project management. In the view of the PMBOK® Guide, other important knowledge areas are: time, cost, quality, communication, risk etc.

The PMBOK® Guide treat a project like a sum of processes. Thus, the last edition of this guide considers that Project human resource management includes the following processes:

- Human resource planning;

- $\quad$ Acquire project team;

- Develop project team;

- Manage project team.

Every process is defined by three elements: inputs, tools and techniques and outputs. The relationship between human resource management processes are showed in the following picture:

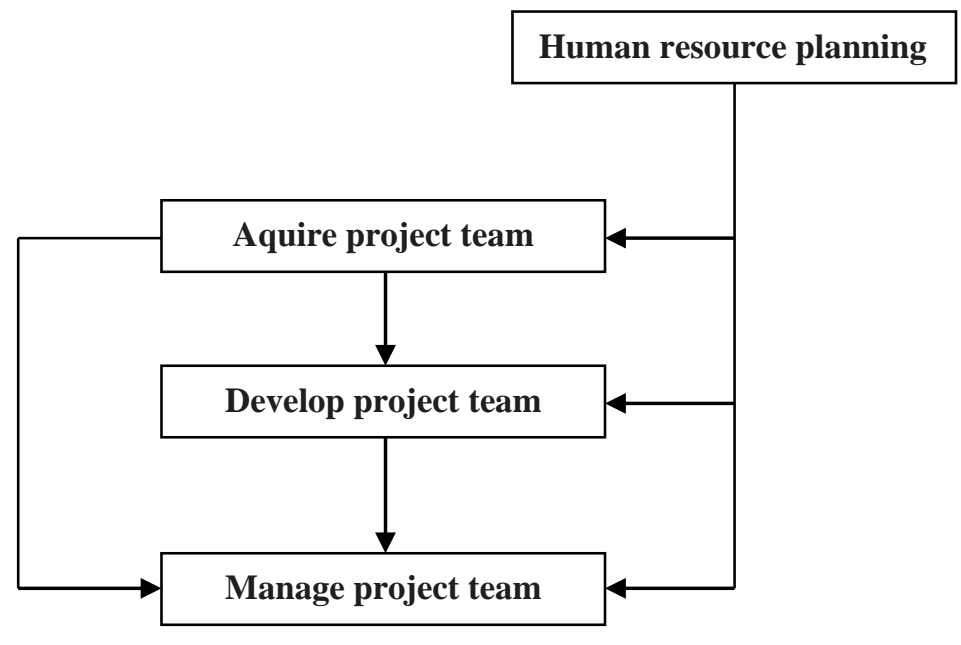

Figure 1. The relationship between human resource management processes Source: Adapted by PMI, PMBOK®Guide (2012), $5^{\text {th }}$ Edition, USA, pp. 257

\subsection{Human resource planning}

As stated by PMI (2012) in the last edition of the PMBOK® Guide, "Human Resource Planning is the process of identifying and documenting project roles, responsibilities, required skills, reporting relationships, and creating a staffing management plan".

The main result (output) of this process is the Human Resource Management Plan. This plan is an important part of the Project Management Plan. In order to elaborate the Human Resource Management Plan can be used several tools and techniques such as: organizational chart and position description, organizational theory, expert judgment etc. In practice, we can use several formats to document team member roles and responsibilities: hierarchical, matrix and text-oriented.

An example of responsibility assignment matrix is the RACI (Responsible, Accountable, Consult, and Inform) chart: 
Table 1. RACI Matrix

\begin{tabular}{|l|l|l|l|l|l|}
\hline & \multicolumn{5}{|c|}{ Person } \\
\hline Activity & Popescu & Ionescu & Vasilescu & Mihaescu & Liescu \\
\hline Activity no. 1 & A & I & R & I & C \\
\hline Activity no. 2 & I & A & C & R & C \\
\hline$\ldots \ldots \ldots \ldots \ldots \ldots . .$. & . &. &. &. &. \\
\hline Activity no.... & A & I & R & I & I \\
\cline { 4 - 6 } & &
\end{tabular}

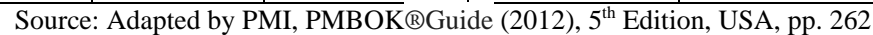

This chart presents all activities, all people associated with a certain activity and their responsibilities. For every activity must be designate only one accountable person.

\subsection{Acquire project team}

As stated by PMI (2012) in the last edition of the PMBOK ${ }^{\circledR}$ Guide, “Acquire Project Team is the process of confirming human resource availability and obtaining the team necessary to complete project activities".

The project team can come from inside the organization and/or from outside the organization. In any case, the project manager must pay attention to several criteria, in order to acquire the best project team: the availability, the cost, the experience, the attitude, the ability, the knowledge and the skills of the human resource.

\subsection{Develop project team}

As stated by PMI (2012) in the last edition of the PMBOK ${ }^{\circledR}$ Guide, "Develop Project Team is the process of improving competencies, team member interaction, and overall team environment to enhance project performance”.

The main tools and techniques used for Developing Project Team are:

- Interpersonal skills, such as communication skills, emotional intelligence, conflict resolution, negotiation, influence, team building etc.

- $\quad$ Training activities, that are used to develop the competencies of the project team members;

- Team-building activities, that are used to develop the interpersonal relationships;

- Ground rules, that are used to impose a good behavior within the project team;

- Recognition and rewards an appropriate behavior.

- Co-location etc.

The development of the project team can contribute decisively to project success. The project success is recorded when all the objectives are reached and all the planned activities of the project are completed.

\subsection{Manage project team}

As stated by PMI (2012) in the last edition of the PMBOK® Guide, "Manage Project Team is the process of tracking team member performance, providing feedback, resolving issues, and managing team changes to optimize project performance”. The main tools and techniques used for Manage Project Team are:

- Observation and conversation, that are used when the project manager wants and can to be in direct contact with the project team members;

- $\quad$ Project performance appraisals, that can be made by project manager having as starting point the appraisals realized by the project members, by the project supervisors or by the project stakeholders; 
- Conflict management, that is a technique used in order to solve the conflict which may occur during the project;

- Interpersonal skill such as leadership, influencing and effective decision making;

- $\quad$ Issue log etc.

\section{Aspects regarding human resource in the Prince2 standard}

The name of this standard is an acronym for Projects IN Controlled Environments. The PRINCE method was elaborated in the UK, in 1989. In 1996 this method was replaced with PRINCE2. The last update of this standard was made in 2009.

The approach of this standard is based on seven main processes and on seven themes (such as: plans, quality, organization etc.). The Prince2 method don't analyze the human resources like a distinct theme but in every process and theme is about the human resources. The Prince 2 theme regarding organization try to explain very clearly the responsibilities of the human resources within the project. This theme don't takes into account only the accountability and responsibility of the project team and of the project manager. Also, in this part of the standard is presented the responsibilities of the main stakeholders (business, user and supplier).

In this standard, the responsibilities are viewed like a roles. Everybody involved in the project can have one or more roles and a role can be fulfilled by several persons.

Prince2 proposed four level of authority for an organization: one outside the project (corporate or program management) and three inside the project (project board, project manager and team manager).

As stated by Office of Government Commerce (2009), the project board play an important role. This board is composed of senior managers who owns the project and who are responsible for the project direction/managing. The manner in which the project board direct the project can make the difference between success and failure of the project. The Project Board has three main roles. Every role represents the main interests of business (executive role), user (senior user role) and supplier (senior supplier role).

Another important concept concerning human resources used in Prince2 is project management team. This concept emphasis that all managers must working together as a real team in order to ensure the success of the project. Also, this concept presents all the management roles in the PRINCE2 standard. If Project Board must ensure the project direction, the project manager has the responsibility for the daily management of the project. The project team must undertake all activities involved in the project. This team has a "chief” named Team Manager. The Team Manager must perform the daily management of the project, must monitor the manner in which are undertaken the project activities and report this to the Project Manager.

In order to ensure the success of the project, Prince2 propose two distinct structures: the Project Assurance and the Project Support. The Project Assurance (business, user and supplier assurance) is very similar like an audit while the Project Support provides administrative services for managers as stated by Graham (2010): 


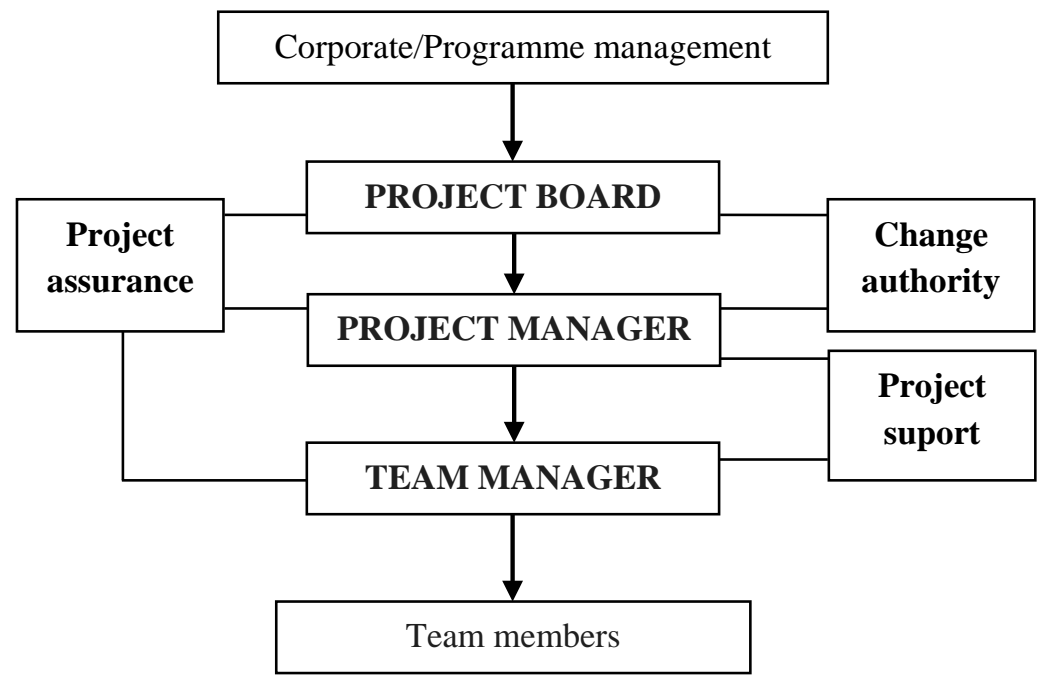

Figure 2. The Project Management Team in the Prince2 standard

Source: Adapted by Graham, N., Prince2 for Dummies (2010), $2^{\text {th }}$ Edition, John Wiley \& Sons Ltd., England, pp. 193

\section{Conclusions}

In practice, are used several standards concerning project management. These standards propose many recommendations regarding the best use of the human resource within the project. In the PMBOK ${ }^{\circledR}$ Guide the human resource is considered one of the most important knowledge areas of the project management and is analyzed within a distinctly chapter named Project human resource management. The PMBOK ${ }^{\circledR}$ Guide presents in detail the main tools and technics which can be used in order to make the human resource more efficient. The Prince 2 method don't analyze the human resources within a distinct chapter. The approach of this standard is focused on the roles and responsibilities of the human resource within the project.

Even if between guidelines, standards and methodologies (methods) of project management there are many differences, their main goal is common: to provide the best recommendations and practice to manage project to success. The human resource is very important for the success of the project. Therefore, this should be used both effective and especially efficient.

\section{References}

Drob, C., Zichil, V. (2013), Overview regarding the main guidelines, standards and methodologies used in project management, Journal of Engineering Studies \& Research, Vol. 19 Issue 3, pp.26-31.

Graham, N. (2010), Prince2 for Dummies (2 ${ }^{\text {th }}$ edition), John Wiley \& Sons Ltd., England.

Office of Government Commerce (2009), Managing and Directing Successful Projects with PRINCE2 (2009 edition), The Stationery Office, UK.

Project Management Association of Japan (2005), A Guidebook of Project \& Program Management for Enterprise Innovation, Vol I, available on http://www.pmaj.or.jp/ENG/P2M_Download/P2MGuidebookVolume1_06011 2.pdf, and Vol II, available on http://www.becausei.org/P2MGuidebookVolume2_041014.pdf.

Project Management Institute (2012), PMBOK®Guide (5 ${ }^{\text {th }}$ Edition), USA. 